\title{
Definition features of the efficiency in railways management
}

\author{
Oleksandr Deineka ${ }^{1}$, Liubov Pozdniakova ${ }^{2}$, Olena Sementsova ${ }^{1 *}$, and Yuliia Krykhtina ${ }^{1}$ \\ ${ }^{1}$ Ukrainian State University of Railway Transport, Management and Administration Department, \\ Feuerbach sq., 7, Kharkiv, 61050, Ukraine \\ ${ }^{2}$ Ukrainian State University of Railway Transport; Economics, Business and Personnel Management \\ on Transport Department, Feuerbach sq., 7, Kharkiv, 61050, Ukraine
}

\begin{abstract}
The article deals with the determination of general effectiveness of managerial influences on the activity of the railway industry, taking into account such partial indicators as public, functional and economic efficiency. appropriate degree of satisfaction of requirements and expectations of consumers on the quality of transport services, as well as the degree of satisfaction of staff with the work conditions are used to assess the public effectiveness of management in railway transport. Functional efficiency of management in railway transport can be estimated by the conformity of managerial decisions to the functional goals and tasks of management, achievement of optimal results within the requirements of state regulation of the industry, etc. The economic efficiency of railway transport management has traditionally been evaluated by the degree of maximization of profitability of freight transport and minimization of losses from passenger transportation with rational use of industry resources.
\end{abstract}

\section{Problem statement}

It is well known that the railway industry at any time of historical development has had the status of a carrier of national strategic importance. It has always been due to the several factors. First, it is the crucial role of the railways in ensuring national security and defense; and, secondly, the exclusive role of rail transport in the connection of sectors of the national economy. In view of this, the railway industry has always experienced a special administrative influence of the government on the implementation of production and economic activity. Today, relations between the government and society are increasingly transformed from rigid centralized administration towards open, transparent, democratic governance. It happens due to the request of the railway industry reform in order to integrate it into international transport infrastructure, as well as the globalization of the national economy. In view of this, issues concerning the clarification and detailing of methodological tools for assessing the efficiency of railways management become more and more relevant.

${ }^{*}$ Corresponding author: $\underline{\text { sementsova.elen@gmail.com }}$ 


\section{Analysis of research and publications}

By conducting an analytical study of global experience in evaluating the effectiveness of management in rail transport, it can be noted that the majority of researchers try to improve the evaluation of the effectiveness of using certain resources (such as labor, energy, etc.).

We [1] stressed the need to improve the assessment of the efficiency of management of labor resources of railway companies. They propose to improve the method of measuring labor productivity of personnel, which should be based on the assessment of the level of development of human potential. According to them, such an approach is generated by the need to adapt the performance management system and motivation staff to dynamically change the environmental factors.

The main purpose of [2] is to assess the efficiency of energy resources. The authors reveal the principles of assessing the energy efficiency of trains with electric traction, limiting existing systems, measuring and processing information on electricity consumption, "bottlenecks" of the traction power system, etc.

In [3], the authors substantiated the approach to assessing the economic efficiency of railway enterprises, which considers the natural environment as an active element of management. In assessing the economic efficiency of the enterprises, the authors are limited considering the environmental aspect of their functioning and suggest to take into account non-productive costs, as well as the formation of effective interaction of railway enterprises and society in solving environmental problems.

In contrast to the above-mentioned works, other authors [4] offer a comprehensive approach to determining the efficiency of railways. They emphasize the importance of analyzing the efficiency of management in logistics infrastructure.

They compare the Stochastic-DEA and Fuzzy-DEA models to assess the impact of randomness and fuzziness in the indicators of the volume of railway operations (inputs and outputs) for ranking the efficiency of railways functioning in the example of 5 countries in Asia: Japan, Thailand, Vietnam, Malaysia, and Indonesia.

A significant number of works are devoted to the aspects of determining the effectiveness of rail transport management in Ukraine and on individual directions of its work in particular [5-10].

The work by $\mathrm{Yu}$. S. Barash [5] is generally concerned with improving the competitiveness of Ukrainian railways. It proposes an economic criterion for choosing the best rail transport management model. The study conducted by V. L. Dykan, M. V. Korin [6] focuses on the aspects of the impact of the globalization of economic systems on the functioning of the railway industry and its management.

O. M. Kirilenko [7] focuses on the determination of the efficiency of the operation of sites with low traffic intensity. P. O. Yanovskyi [8] is limited to the study of financial results to evaluate the efficiency of the operation of the suburban passenger complex in Ukraine. In [9], V. A. Zadoia approaches to assessing the efficiency of railways functioning are presented, based on indicators of economic efficiency. M.P. Sinhaievska [10] also studies the evaluation of the economic efficiency of railways functioning and provides analytical models for determining the influence of factors (extensive and intense) on the financial results of the industry.

The effectiveness of management on the railways of Ukraine cannot be assessed without analyzing the main volumes of operation of the industry, because they describe the results of the implementation of managerial influences. The analysis of public reporting on the results of the Ukrainian railway [11] indicates significant fluctuations in the scope of their work (Fig. 1). 


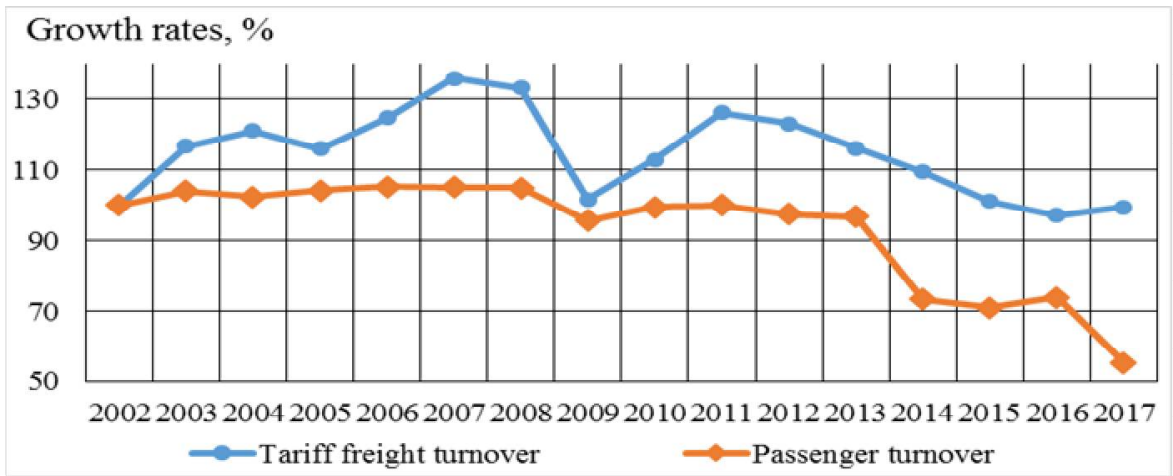

Fig. 1. Growth rate of tariff freight turnover and passenger turnover in the calculation before the first year (2002) of the analyzed period [developed by authors by source 11].

In general, during the analyzed period, the volumes of cargo and passenger transportation tended to decrease. This is especially true for passenger traffic which decreased almost twice during the period has. On the other hand, the cargo turnover has almost a stable position for growth during the first five years of the period, but the global economic crisis in 2008 had a significant negative impact on the Ukrainian economy, and the rail transport experienced a significant reduction of demand for freight during 2008-2009 (more than $35 \%$ ). In the following two years, the revival of economic ties has made it possible to almost restore lost positions. But further, again there was a reduction in the number of services for the transportation of goods, due to the loss of competitive positions in the market of transport services. In the subsequent period (after 2014), this tendency was aggravated by a decrease in cargo flows due to military actions and loss of control over certain territories, which led to the loss of the image of Ukraine as a transit state.

Along with the decline in the total volumes of cargo and passenger transportation by rail, the contingent occupied by the main activity (Fig. 2) has a steady upward trend even in times of worsening of the recession, which led to a significant loss of traffic volumes. This fact proves the ineffective use of labor resources on the railways and worsens the overall efficiency of railways. However, the pace of change in the contingent of management is entirely consistent with changes in the volumes of transportation of railways.

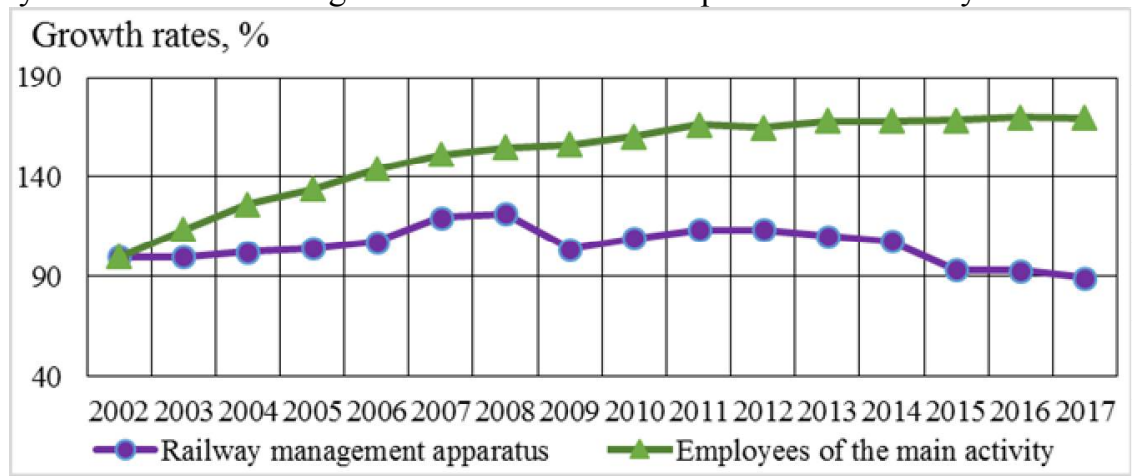

Fig. 2. The growth rate of the number of railway management apparatus and the average number of employees of the main activity in the calculation before the first year (2002) of the analyzed period [developed by authors by source 11].

Despite the recession in the national economy, the railways continue to increase the 
operational length of the track to improve the railway infrastructure to integrate into the European community and the globalization of the national economy. When investigating the efficiency of railways management, it is interesting to study the ratio of abovementioned indicators (tariff freight turnover, passenger turnover, number of railway management apparatus and the average number of employees of the main activity) and operating length railroad (Fig. 3).

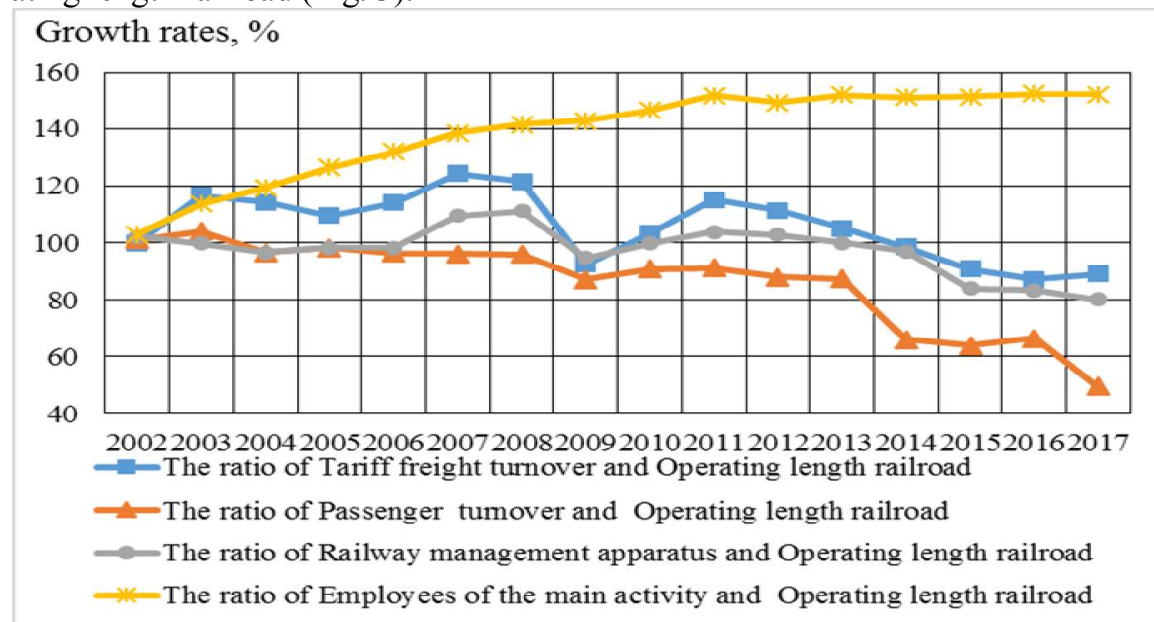

Fig. 3. Growth rate of the ratio of tariff freight turnover, passenger turnover, the number of the railway management apparatus and contingent of the main activity of the operating length railroad of Ukraine up to the first (2002) year of the analyzed period [developed by authors by source 11].

The figures in the graphs also illustrate the deterioration of the analyzed indicators, although at a slightly lower pace than in previous calculations. This situation proves the expediency of improving the management activity of the railway industry of Ukraine to increase efficiency.

\section{Presentation of the main research}

Summing up the conducted review of scientific publications on the assessment of the effectiveness of managerial impacts on the railway industry, it can be concluded that a limited number of studies on a comprehensive assessment of the efficiency of rail transport management. Analytical calculations testify to the necessity of improving the management activity in the railway industry to increase its efficiency.

General evaluation of the effectiveness of managerial influences on the railway industry activity is proposed to determine the aggregate of such most important partial indicators as public efficiency, functional efficiency, and economic efficiency.

The components of a generalizing indicator of the effectiveness of managerial influences on the railway industry activities are described in more detail in article [12]. The tools for assessing the effectiveness of management in the railways are shown in Fig. 4.

As partial criteria for assessing the public effectiveness of management in railway transport, it is advisable to distinguish:

- degree of satisfaction of requirements and expectations of consumers on the quality of transport services;

- the degree of staff satisfaction with the conditions of stay in the organization.

Estimating the degree of satisfaction of requirements and expectations of consumers about the quality of transport services should be carried out through satisfaction of passengers with quality of service, convenience of schedule, time of stay on a trip, 


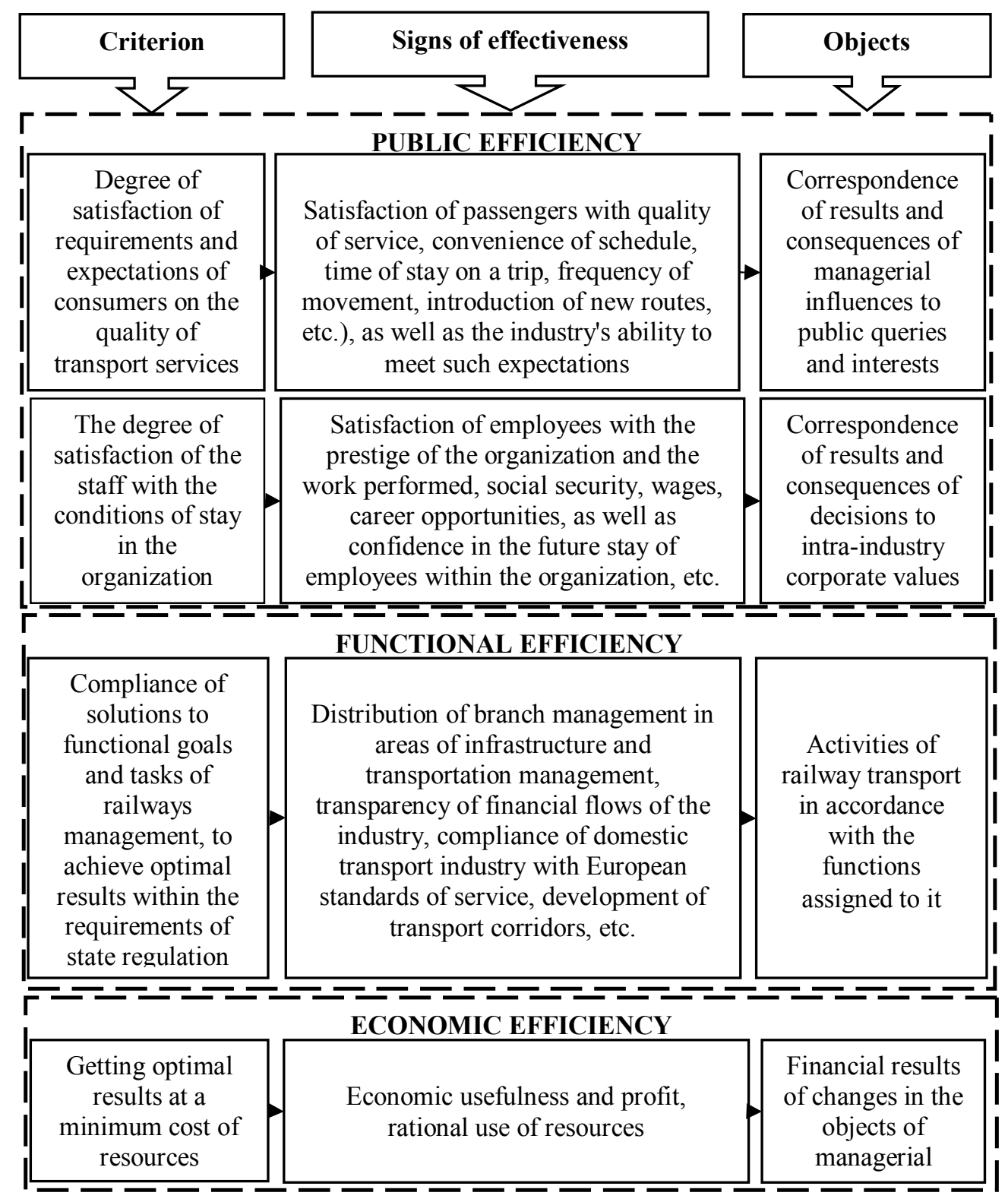

Fig. 4. Tools for assessing the effectiveness of management in the railway transport.

frequency of movement, introduction of new routes, etc.), as well as the industry's ability to meet such expectations.

Assessment of the degree of satisfaction of the organization's staff with the conditions of stay in the organization is carried out through satisfaction of the employees with the prestige of the organization and the work performed, social security, pay, career opportunity, as well as confidence in the future stay of employees within the organization, etc.

For measuring public effectiveness, expert appraisal methods are predominantly used. Unfortunately, the results of such an assessment have a certain subjectivity, which 
determines the probability and variability depending on the focus group of consumers and experts involved in the process of evaluation, the accuracy of the formulation of relevant issues for the railway industry, communication obstacles, etc.

The criteria for evaluating the functional efficiency of management in the railway transport can relevance of solutions to the functional objectives and tasks of management in the rail transport, achieving optimal results in accordance with the requirements of state regulation of the industry, the compliance of solutions with the expectations of competitors. The object of the evaluation of this criterion is the activity of the railway transport, respectively, the functions assigned to it. For the measurement of functional efficiency, the methods of expert evaluation are also used predominantly.

The criteria for assessing the economic efficiency of rail transport management traditionally include maximizing the profitability of freight traffic and minimizing losses from passenger transport when the industry's resources are used rationally. The objects of assessing under this criterion are the financial results of managerial influences that arise in the implementation of financial and economic activities. To measure economic efficiency, it is advisable to apply methods based on the formalized approach, which provides an opportunity to obtain an accurate, objective and reasoned assessment of the results of managerial influences.

\section{Conclusion}

The study of tools for assessing the effectiveness of management in rail transport creates conditions for conducting a qualitative, systematic and integrated analysis of managerial impacts on the functioning of railways, which will be the basis for making appropriate management decisions on the reform and integration of the national rail network to the international transport infrastructure.

\section{References}

1. A. Davydov, A. Dementev, V. Burovtsev, MATEC Web of Conferences, 239 (2018)

2. V. Cheremisin, M. Nikiforov, A. Kashtanov, S. Ushakov, Advances in Intelligent Systems and Computing, 692, 83-90 (2018)

3. J. A. Tagiltseva, E. L. Kuzina, N. A. Drozdov, M. A. Vasilenko, International Conference "Quality Management, Transport and Information Security, Information Technologies", 163-168 (2018)

4. P. Wanke, M. A. Kalam Azad, Transportation Planning and Technology, 41, 573-599 (2018)

5. Yu. S. Barash Upravlinnia zaliznychnym transportom krainy (Dnipropetr. nats. un-t zalizn. transp. im. akad. V. Lazariana, Dnipropetrovsk, (2006)

6. V. L. Dykan, M. V. Korin, The bulletin of transport and industry economics, 33, 13-19 (2011)

7. O. M. Kyrylenko, Zabezpechennia efektyvnosti funktsionuvannia malodiialnykh dilnyts PAT «Ukrzaliznytsia» (Dnipropetr. nats. un-t zalizn. transp. im. akad. V. Lazariana, Dnipro, (2018)

8. P. O. Yanovskyi, Zaliznychnyi transport Ukrainy, 5, 9- 12 (2009)

9. V. O. Zadoia, Zbirnyk naukovykh prats Ukrainskoi derzhavnoi akademii zaliznychnoho transportu, 153, 15-19 (2015)

10. M. P. Sinhaievska, Problemy informatyzatsii ta upravlinnia, 13, 105-113 (2005)

11. Dovidnyk osnovnykh pokaznykiv roboty rehionalnykh filii PAT «Ukrainska Zaliznytsia» (Upravlinnia statystyky PAT «Ukrainska Zaliznytsia», Kyiv, (2018)

12. O. H. Deineka, O. V. Sementsova, O. L. Vasyliev, The bulletin of transport and industry economics, 59, 204 - 207 (2017) 